\title{
Does Lycium europaeum leaf have antihyperglycemic, antihyperlipidemic and antioxidant effects
}

\author{
Rabeb Tej ${ }^{1}$, Amel Hamdi ${ }^{1}$, Raja Serairi Beji ${ }^{2}$, Wissem Aidi Wannes ${ }^{2 *}$, Iness Bettaieb Rebey ${ }^{2}$, Samia \\ Oueslati $^{2}$, Riadh Ksouri ${ }^{2}$, Moufida Saidani Tounsi ${ }^{2}$, Mokhtar Lachaal ${ }^{1}$, Najoua Karray Bouraoui ${ }^{1}$

\begin{abstract}
${ }^{1}$ Unité de Physiologie et de Biochimie de la Réponse des Plantes aux Contraintes Abiotiques, Faculté des Sciences de Tunis, Campus Universitaire Tunis El Manar, Tunisia, ${ }^{2}$ Laboratory of Aromatic and Medicinal Plants, Center of Biotechnology of the Technopole Borj-Cedria, Hammam-Lif. Tunisia
\end{abstract}

\begin{abstract}
The purpose of the present investigation is to assess, for the first time, the antidiabetic, antihyperlipidemic and antioxidant activities of Lycium europaeum extract in alloxan-induced diabetic rats. Diabetes was induced in adult male Wistar rats via a single subcutaneous alloxan injection $(120 \mathrm{mg} / \mathrm{kg})$. Lycium europaeum aqueous extract was orally administered at a dose of $20 \mathrm{mg} / \mathrm{kg}$ for 28 consecutive days. Serum concentrations of total cholesterol (TC), low-density lipoprotein cholesterol (LDL-C), high-density lipoprotein cholesterol (HDL-C) and triglycerides (TG) were assayed at the end of the experimental period in all investigated groups. Antioxidant enzymes such as glutathione peroxidase (GPx), catalase (CAT) and superoxide dismutase (SOD) were sought in the serum and pancreas. Lycium europaeum extract significantly increased HDL-C and reduced blood glucose, TC, LDL-C and TG as compared to the alloxan-control group. Lycium europaeum extract was also efficient in reducing oxidative stress in diabetic rats by increasing SOD, CAT and GPx activities both in the pancreas and the plasma of the animals. Moreover, Lycium europaeum extract contained considerable levels of polyphenols and flavonoids. It also exhibited an important antioxidant capacity and a remarkable ability to quench DPPH radicals and reduce irons. The obtained results highlight potentially relevant health beneficial effects of Lycium europaeum extract, reversing hyperglycemic, hyperlipidemic and oxidative stress effects in rats with alloxan-induced diabetes. Therefore, it may be considered as a promising alternative or complementary agent to diabetes treatment.
\end{abstract}

Keywords: Lycium europaeum/extract/antihyperglycemia. Lycium europaeum/extract/antioxidant activity. Lycium europaeum/extract/antihyperlipidemia.

\section{INTRODUCTION}

Diabetes mellitus (DM) is a chronic endocrine metabolic disorder that poses a major public health problem around the world. The World Health Organization (WHO) predicted it would be the $7^{\text {th }}$ leading cause of death by 2030 (WHO, 2011). The progressive spreading of diabetes in both developed and developing countries has challenged scientists to conduct further investigation seeking potent therapeutic agents from natural sources for a more efficient use in the treatment and management of diabetes (Gupta et al., 2012). DM is defined as a degenerative and chronic disease induced when the

\footnotetext{
*Correspondence: W. Aidi Wannes. Laboratoire des Plantes Aromatiques et Médicinales, Centre de Biotechnologie de Borj-Cedria, B.P. 901, 2050 Hammam-Lif, Tunisie. Tel: +21679325738; Fax: +21679412638. E-mail: aidiwissem@yahoo.fr (iD
}

pancreas does not produce sufficient insulin, or when the body cannot effectively process this hormine (WHO, 2006). Diabetes frequently leads to serious complications (Deshpande, Harris-Hayes, Schootman, 2008), namely nephropathy, neuropathy and retinopathy (Winkler et al., 2010), which can be delayed and reduced by maintaining tight glycemic control. Additionally, glucose homeostasis disorders also involve abnormalities in lipid metabolism characterized by a reduced cholesterol rate in high-density lipoprotein and increased triglyceride, total cholesterol and cholesterol rates of low-density lipoprotein (Capewell et al., 2010). In fact, hyperlipidemia poses a major risk for the premature development of atherosclerosis and cardiovascular complications (Goldstein et al., 1973).

In the past few decades, increasing evidence has connected oxidative stress to a variety of pathological diseases, including DM (El Faramawy, Rizk, 2011). 
Over time, convincing evidence has established the role of free radicals and oxidative stress in the pathogenesis and development of complications emanating from DM. The possible sources of oxidative stress in diabetes might include glucose auto-oxidation, redox balance shifts, decreased tissue concentrations of low molecular weight antioxidants (vitamin E) and impaired activities of antioxidant defense enzymes as superoxyde dismutase and catalase (Haskins, BradLey, 2003).

An effective management of diabetes requires combined multiple therapeutic approaches: exercise and diet. In fact, synthetic drugs are effectual in DM treatment but restricted by their limited action, pharmacokinetic properties, secondary failure rates and numerous side effects including hypoglycemia, damage to liver, lactic acidosis, diarrhea, abdominal pain, weight loss and loss of appetite (Dey, Attele, Yuan, 2002). Hence, safer and more effective antidiabetic drugs are deemed requisite. Nowadays, several people around the world are using natural remedies solely or in combination with their hypoglycemic drugs to manage their diabetes. As plants are safe and cost-effective (Punithavathi et al., 2011; Sefi et al., 2010), various herbal medicines and medicinal plants have been traditionally used for the control, management and/or treatment of diabetes (Ramachandran, Rajasekaran, Manisenthilkumar, 2012). To date, over 800 species have been investigated and their hypoglycemic effect reported (El-Abhar, Schaalan, 2014). Medicinal plants with antioxidant activity have been scrutinized for their hypoglycemic activities. Consequently, medicinal plant screening for therapeutic schemes is important in drug development, as plants may possess hypoglycemic, hypolipidemic and antioxidant activities, which may be effective in the treatment of this chronic disease (Tiwari, Rao, 2002).

Boxthorn (Lycium europaeum) belongs to the Solanaceae family and occurs spontaneously around the Mediterranean basin with three other species, namely $L$. barbarum, L. shawii, and L. chinense. These species have widely been used in traditional medicine. In fact, the $L$. shawii root decoction is widely renowned to treat mouth sores, cough, high blood pressure and diabetes. Fruit of this plant is also consumed for its antioxidant and other beneficial properties (Said et al., 2002). Concerning $L$. barbarum, several studies have indicated its benefits on aging, neuroprotection, general well-being, fatigue/ endurance, metabolism/energy expenditure, glaucoma, immunomodulation, antitumor activity and cytoprotection (Amagase, Farnsworth, 2011) as well as hypoglycemic and antioxidant effects in cell or animal experiments (Jin et al., 2013; Zhu et al., 2013; Zhao et al., 2009; Luo et al., 2004).
In Tunisia, the L. europaeum species is widely used as a functional food and as a medicinal herb in the treatment of diabetes without an adequate knowledge base. However, to the best of our knowledge, the anti-diabetic effect of $L$. europaeum leaves has not been explored. For this reason, the goal of the present study was to investigate the anti-diabetic, antihyperlipidemic and antioxidant activities of boxthorn leaves in alloxan-induced diabetic rats.

\section{MATERIAL AND METHODS}

\section{Plant material}

Fresh and mature whole boxthorn plants were collected in December 2016 from Jdaida (35 33' 18" North, 9० 59' 1" East of Tunis, Tunisia). Botanical identification was carried out and a voucher specimen AMP 561 was deposited at the faculty of Science, University of Tunis El Manar of Tunisia. Boxthorn leaves were washed with water, dried at room temperature in the dark and then ground to a fine powder in a Mettler AE 200 (Dangoumau type) grinder.

\section{Preparation of plant extract}

$75 \mathrm{~g}$ of the powder was soaked in 11 boiled water at $100^{\circ} \mathrm{C}$ for $15 \mathrm{~min}$ for extraction (Ayiguli et al., 2007). The water extract was filtered with $\mathrm{N}^{\circ} 3$ Whatmann Millipore filter paper and subjected to freeze drying yielding $20.0 \mathrm{w} / \mathrm{w}$ of dry material that was stored in refrigerated amber glass containers. This procedure was repeated weekly throughout the study.

\section{Total phenolic content}

Total phenolic content of the aqueous extract from $L$. europaeum leaves was determined using the Folin-Ciocalteu reagent (Dewanto et al., 2002). An aliquot $(0.125 \mathrm{~mL})$ of a suitable diluted leaf extract $(50-400 \mathrm{mg} / \mathrm{mL})$ was added to $0.5 \mathrm{~mL}$ of deionized water and $0.125 \mathrm{~mL}$ of the Folin-Ciocalteu reagent. The mixture was shaken and allowed to stand for $6 \mathrm{~min}$, before adding $1.25 \mathrm{~mL}$ of $7 \% \mathrm{Na}_{2} \mathrm{CO}_{3}$ solution. The solution was then adjusted with deionised water to a final volume of $3 \mathrm{~mL}$ and mixed thoroughly. After incubation for $90 \mathrm{~min}$ at $23^{\circ} \mathrm{C}$, the absorbance versus prepared distilled water blank was read at $760 \mathrm{~nm}$ with an UV-Visible spectrophotometer. Total phenolic content of leaves was expressed as $\mathrm{mg}$ gallic acid equivalents per gram of dry weight (mg GAE/g DW) through the 
calibration curve with gallic acid. The calibration curve range was $50-400 \mathrm{mg} / \mathrm{mL}\left(R^{2}=0.99\right)$. All samples were analyzed in triplicate.

\section{Total flavonoid content}

Total flavonoid content of the aqueous extract from $L$. europaeum leaves was determined by a colorimetric assay according to Dewanto et al. (2002). An aliquot $(250 \mathrm{~mL})$ of a suitable leaf extract $(50-500 \mathrm{mg} / \mathrm{mL})$ was mixed with 75 $\mathrm{mL} \mathrm{NaNO}_{2}(5 \%)$. After $6 \mathrm{~min}, 150 \mathrm{~mL}$ of $10 \%$ aluminium chloride was added and $5 \mathrm{~min}$ later, $500 \mathrm{~mL}$ of $\mathrm{NaOH}$ (1M) was added. Finally, the mixture was adjusted to 2.5 $\mathrm{mL}$ with distilled water. The absorbance versus prepared distilled water blank was read at $510 \mathrm{~nm}$ with a UV-Visible spectrophotometer. Total flavonoid content of leaves was expressed as mg catechin equivalents per gram of dry weight (mg CE/g DW) through the calibration curve with catechin in the range of $50-500 \mathrm{mg} / \mathrm{mL}$. All samples were analyzed in triplicate.

\section{Evaluation of antioxidant capacity}

Total antioxidant capacity of aqueous extract from L. europaeum leaves was determined through the assay of the green Phosphate/ $\mathrm{Mo}^{5+}$ complex according to the method described by Prieto, Pineda and Aguilar (1999). An aliquot $(0.2 \mathrm{~mL})$ of sample extract was combined with $2 \mathrm{~mL}$ of reagent solution $(0.3 \mathrm{~N}$ Sulfuric acid. $28 \mathrm{mM}$ sodium phosphate and $4 \mathrm{mM}$ ammonium molybdate). Methanol (80\%) was used instead of sample for the blank. The tubes were capped and incubated in a boiling water bath for $90 \mathrm{~min}$. Then, samples were cooled to room temperature and the absorbance was read at $695 \mathrm{~nm}$ against blank. Antioxidant capacity was expressed as mg gallic acid equivalent per gram dry weight (mg GAE/g DW). All samples were analyzed in triplicate.

\section{Scavenging ability on DPPH radical}

The ability of the corresponding extracts to donate hydrogen atoms or electrons was measured from the bleaching of a purple colored methanol solution of 1.1-diphenyl-2- picrylhydrazyl (DPPH), according to the method described by Hatano et al. (1988). $1 \mathrm{~mL}$ of various concentrations $(1-100 \mu \mathrm{g} / \mathrm{mL})$ of $L$. europaeum leaf extract was added to $250 \mu 1$ of $0.2 \mathrm{mM} \mathrm{DPPH}$ radical solution in methanol. The mixture was shaken vigorously and allowed to stand for $30 \mathrm{~min}$ in the dark. The absorbance of the resulting solution was read at $517 \mathrm{~nm}$ and butylatedhydroxyl toluene (BHT) was used as positive control. Inhibition of DPPH radical was calculated as follows:

$$
\text { DPPH scavenging effect } \left.(\%)=\left(\left(\mathrm{A}_{\mathrm{c}}-\mathrm{A}_{\mathrm{S}}\right) / \mathrm{A}_{\mathrm{c}}\right)\right) \times 100
$$

where $\mathrm{A}_{\mathrm{c}}$ and $\mathrm{A}_{\mathrm{S}}$ are the absorbance at 30 min of the control and the sample, respectively. The anti-radical activity was expressed as $\mathrm{IC}_{50}(\mu \mathrm{g} / \mathrm{mL})$, the extract dose required to cause a $50 \%$ decrease of the absorbance at $517 \mathrm{~nm}$. A lower $\mathrm{IC}_{50}$ value corresponded to a higher antioxidant activity. All samples were analyzed in triplicate.

\section{Iron reducing power}

Iron reducing power was determined according to the method of Oyaizu (1986). $1 \mathrm{~mL}$ of sample extracts at different concentrations $(30,60,90,120$ and $150 \mathrm{mg} / \mathrm{mL})$ was mixed with $2.5 \mathrm{~mL}$ phosphate buffer $(0.2 \mathrm{M}, \mathrm{pH}$ 6.6) and $2.5 \mathrm{~mL}$ potassium ferricyanide $(1 \mathrm{~g} / 100 \mathrm{~mL})$. After incubation at $50^{\circ} \mathrm{C}$ for $20 \mathrm{~min}$, the mixture was added to $250 \mu \mathrm{l}$ of thichloroacetic acid $(10 \mathrm{~g} / 100 \mathrm{~mL})$ and then centrifuged at $3500 \mathrm{r} / \mathrm{min}$ for $10 \mathrm{~min}$. As soon as $400 \mu \mathrm{L}$ supernatant was aliquoted into $400 \mu \mathrm{FeCl}_{3}(0.1 \mathrm{~g} / 100 \mathrm{~mL}$ in distilled water), the timer was started. At $90 \mathrm{~s}$, the absorbance was read at $700 \mathrm{~nm}$ (Unico 2100, Shangai, China) against ascorbic acid as authentic standard. Higher absorbance of the reaction mixture indicates higher reducing power. EC50 value $(\mu \mathrm{g} / \mathrm{mL})$ is the effective concentration of the extract at which the absorbance was 0.5 and it was obtained from linear regression analysis. All samples were analyzed in triplicate.

\section{Experimental animals}

All the experimental procedures were carried out in accordance with international guidelines for care use of laboratory animals. Male Wistar rats (15 weeks old, weighing 200-230 g each) were purchased from Pasteur Institute of Tunis (Tunisia) and housed in stainless steel cages under controlled environmental conditions (temperature $22 \pm 1^{\circ} \mathrm{C}$, relative air humidity of $45 \%$ to $55 \%$ with a light/dark cycle of 12 hours). A commercial standard pellet diet (SNA, Borj Cedria, Tunisia) and water were given ad libitum.

\section{Preparation of alloxan-induced diabetic rats}

Induction of diabetes was carried out in rats by administering a single subcutaneous injection of $120 \mathrm{mg} /$ $\mathrm{kg}$ b.w. of a freshly prepared alloxan solution (alloxan monohydrate, Sigma Chemicals Co.), dissolved in acetate 
buffer ( $\mathrm{pH}$ 5.5) and prepared immediately before use. The control groups were injected only with the same volume of acetate buffer as the diabetic groups received. Alloxan induces diabetes through destructing Langerhans islands of the pancreas. Therefore, a large amount of insulin is released from the pancreas cells after the injection. In order to prevent hypoglycemic shock, during the first $24 \mathrm{~h}$ after the alloxan injection, the rats received $10 \%$ dextrose instead of water (Rees, Alcolado, 2005; Kwon, Song, Choi, 2003). Induction of diabetes was confirmed by measuring fasting blood glucose (FBG) three days after alloxan injection. Rats with a blood glucose level of $250 \mathrm{mg} / \mathrm{kg}$ or higher were considered to be diabetic (Ghorbani et al., 2013).

\section{Experimental design}

Twenty-four rats were randomLy divided into four groups of six animals each as follows:

Group (NC): Normal control rats administered distilled water daily;

Group (DC): Diabetic control rats administered distilled water daily;

Group (CLE): Normal rats administered L. europaeum extract at $20 \mathrm{mg} / \mathrm{kg}$ b.w./day for 28 days (p.o.);

Group (DLE): Diabetic rats administered L. europaeum extract at $20 \mathrm{mg} / \mathrm{Kg}$ b.w./day for 28 days (p.o.).

During experiment, blood was collected from tip of the tail vein and fasting blood glucose level was measured once weekly by using a glucose analyzer. At the same time, the body weight of each rat was recorded. At the end of treatment ( $28^{\text {th }}$ day), overnight fasted animals were scarified by decapitation under light anesthesia and blood was collected. Serum samples were obtained by centrifugation at $2200 \mathrm{~g}$ for $15 \mathrm{~min}$ and kept at $-20^{\circ} \mathrm{C}$ for the biochemical assay. The pancreas was removed from each rat, homogenized and analyzed for antioxidant enzymes.

\section{Glucose levels and lipid profile}

Glucose, total cholesterol (TC), HDL-C, and triglyceride (TG) levels were assayed in serum collected at the end of the experiment and using commercial reagent kits purchased from Biomagreb Analyticals (Ariana Tunis, Tunisia). Glucose levels at J7, J14 and J21 were determined with glucometer. LDL-C was estimated by Friedwald method as follows:

LDL cholesterol $=$ total cholesterol - HDL cholesterol (Triglyceride $\div 5$ )
All assessment assays and kits were performed in accordance with the manufacturer instructions and protocols.

\section{Protein analysis in pancreas}

Protein concentration in pancreas tissue was determined according to Lowry et al. (1951), using bovine serum albumin as standard.

\section{Pancreas homogenate preparation}

Animals were euthanized by an over dose of diethyl ether and immediately dissected. The operation was handLed carefully to avoid pancreas damage. The pancreas was taken out, rinsed with saline pre-cooled to $4{ }^{\circ} \mathrm{C}$, the organ was dried with filter paper and weighed after removing adipose and connective tissue. Pancreas homogenates were centrifuged at $3000 \mathrm{rpm}$ for $10 \mathrm{~min}$ at $4{ }^{\circ} \mathrm{C}$ and the supernatant was kept at $-80^{\circ} \mathrm{C}$ until use.

\section{Antioxidant defense system assays}

The activities of three antioxidant enzymes: SOD, CAT and GPx were determined in pancreas homogenate and in serum. SOD activity was determined in pancreas homogenate according to the method of Beyer and Fridovich (1987). This method is based on the capacity of SOD to inhibit the oxidation of nitroblue tetrazolium (NBT). One unit of SOD represents the amount of enzymes required to inhibit the rate of NBT oxidation by $50 \%$ at $25^{\circ} \mathrm{C}$.CAT activity was measured using the method of Aebi (1984). Hydrogen peroxide $\left(\mathrm{H}_{2} \mathrm{O}_{2}\right)$ disappearance was monitored kinetically at $240 \mathrm{~nm}$ for 1 min at $25^{\circ} \mathrm{C}$. The enzyme activity was calculated using an extinction coefficient of $0.043 \mathrm{Mm} / \mathrm{cm}$. GPx activity was measured according to the method of Flohe and Gunzler (1984). GPx activity was quantified according to a coupled enzyme (GPx and glutathione reductase) procedure, which measures the decrease in absorbance at $340 \mathrm{~nm}$ as NADPH is converted to NADP (Nicotinamide adenine dinucleotide phosphate). One unit of GPx activity was recorded as the quantity of enzyme oxidizing $1 \mu \mathrm{mol} \mathrm{NADPH}$ per min

\section{Statistical analysis}

The data were analyzed using the package Stat Graphics plus 5.1 (Stats graphics). Statistical analysis was performed using one-way analysis of variance (ANOVA) followed by Duncan's test for comparison among groups. 
All values were expressed as mean \pm SE. Differences were considered significant if $p<0.05$.

\section{RESULTS}

\section{Total phenolic and flavonoid content of Lycium europaeum leaf extract}

Based on the absorbance values of the various extract solutions compared with the standard solution of gallic acid and catechin, total phenolic and flavonoid amounts were equal to $9.31 \pm 0.02 \mathrm{mg} \mathrm{GAE} / \mathrm{g} \mathrm{DW}$ and $6.01 \pm 17 \mathrm{mg} \mathrm{CE} / \mathrm{g} \mathrm{DW}$, respectively (Table I).

\section{Antioxidant activities of Lycium europaeum leaf extract}

The antioxidant activity of boxthorn extract was explored using three different and complementary assays: total antioxidant capacity, DPPH free radical scavenging and reducing power (Table I). The antiradical activity evaluation of boxthorn aqueous extract displayed an $\mathrm{IC}_{50}$ value equal to $200 \mu \mathrm{g} / \mathrm{mL}$. Besides, our results showed a strong antioxidant capacity of $L$. europaeum leaves (17 mg GAE/g DW). The third antioxidant capacity was measured in terms of the iron reducing power, showing a lower $\mathrm{EC}_{50}$ value equal to $92 \mu \mathrm{g} / \mathrm{mL}$ and thus indicating a high reducing power activity.

\section{Effect of Lycium europaeum on weight body}

Changes in initial and final body weight in control and experimental groups are shown in Table II. Before the experiment start, no difference was observed between studied groups in terms of body weight. The alloxaninduced diabetic rats exhibited a significant loss of the body weight as compared with control. However, boxthorn extract intake induced an increase in body weight in both control and diabetic rats.

\section{Effect of Lycium europaeum on fasting blood glucose level}

As shown in Table II, the administration of alloxan (DC group) led to an elevation of fasting blood glucose levels, which reached a maximum of about $353.7 \pm 30 \mathrm{mg} / \mathrm{dL}$

TABLE I - Total polyphenol, flavonoid contents and antioxidant capacity of Lycium europaeum extract

\begin{tabular}{|c|c|c|c|c|c|}
\hline & $\begin{array}{l}\text { Total polyphenols } \\
\text { (mg GAE/g) }\end{array}$ & $\begin{array}{l}\text { Total flavonoids } \\
\text { (mg CE/g) }\end{array}$ & $\begin{array}{c}\text { Total antioxidant } \\
\text { capacity } \\
\text { (mg GAE/g) }\end{array}$ & $\begin{array}{c}\text { DPPH } \\
(\mathrm{IC50}, \mu \mathrm{g} / \mathrm{mL})\end{array}$ & $\begin{array}{c}\text { Iron reducing } \\
\text { power } \\
(\mathrm{EC50}, \mu \mathrm{g} / \mathrm{mL}) \\
\end{array}$ \\
\hline Leaf extract & $9.31 \pm 0.02$ & $6.01 \pm 0.17$ & $17.24 \pm 0.83$ & $200 \pm 0.05$ & $92 \pm 4$ \\
\hline BHT & - & - & - & $24 \pm 0.20$ & - \\
\hline Ascorbic acid & - & - & - & - & $42 \pm 0.83$ \\
\hline
\end{tabular}

Total phenolic content was expressed by milligram gallic acid equivalent/gram; total flavonoid was expressed by milligram catechin

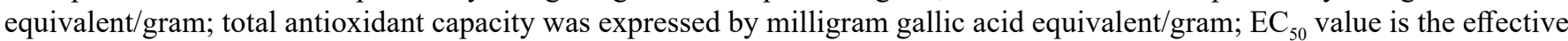
concentration at which the antioxidant activity was $50 \%$; the absorbance was 0.5 for reducing power; 1 , 1-diphenyl-2-picrylhydrazyl $(\mathrm{DPPH})$ radical was scavenged by $50 \%$; The $\mathrm{EC}_{50}$ value was obtained by interpolation from linear regression analysis. BHT and ascorbic acid were used as positive controls; values are the means of 3 replicates \pm SD.

TABLE II - Fasting blood glucose level (mg/dL) and body weight (g) after four weeks of administration of Lycium europaeum extract in normal and alloxan- diabetic rats

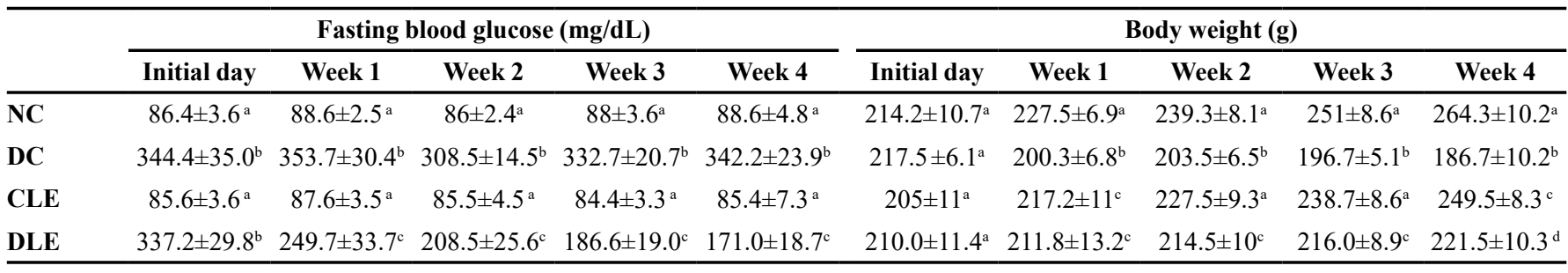

Data are expressed as mean \pm SD of measurements from 6 rats. Groups are labelled as follows: Group NC: normal control, Group DC: diabetic control, Group CLE: Normal control fed with Lycium europaeum extract, Group DLE: Diabetic rats fed with Lycium europaeum extract. Different letters in the same raw indicate significant differences at $P \leq 0.05$ as determined by Duncan's multiple range tests. 
during the first week, and persisted up to four weeks during the experiment. L. europaeum leaf extract exhibited no effect on the blood glucose level in normal rats (NC vs. CLE groups) and an effective hypoglycemic effect started after one week of treatment in diabetic rats (DLE vs DC groups) and continued for four weeks to reach $49.3 \%$ at the end of experimental period.

\section{Effect of Lycium europaeum on lipid profile}

As shown in Figure 1, serum TG, TC and LDL-C levels were significantly increased $(\mathrm{p}<0.05)$ in diabetic groups (DC, DLE) in comparison with controls (NC, CLE); whereas HDL-C was significantly decreased $(p<0.05)$ in the diabetic groups in comparison with controls. In fact, treatment with this plant for four weeks resulted in a reduction in TG, TC and LDL-C compared to untreated diabetic rats while serum HDL-C levels were significantly $(p<0.05)$ increased in treated diabetic rats.

\section{Antioxidant enzyme activities}

Table III shows the antioxidant enzyme activities, namely SOD, CAT and GPx, in the serum and pancreatic homogenate of all the rat groups. Significantly lower pancreatic SOD, CAT and GPx activities $(p<0.05)$ were observed in diabetic rats.

\section{DISCUSSION}

The alloxan-induced rat model was successfully established for the analysis of L. europaeum leaf extractmediated antidiabetic, antihyperlipidemic and antioxidant effects.

Polyphenols and flavonoids are the major contributors of antioxidant activities of the herbs; therefore, they were sought in the L. europaeum leaf extract. Results showed that the total polyphenol and flavonoid amounts that could be extracted from $L$. europaeum leaves were $9.31 \mathrm{mg} \mathrm{GAE} / \mathrm{g}$ DW and $6.01 \mathrm{mg} \mathrm{CE} / \mathrm{g} \mathrm{DW}$, respectively. Rjeibi et al. (2017) showed higher content of polyphenols (15.70 mg GAE DW) and flavonoids (7.64 mg CE/g DW) in the aqueous leaf extract of L. europaeum. Dahech et al. (2013) showed that polyphenol and flavonoid contents of L. shawii fruit ranged from 75 to $377 \mathrm{mg} \mathrm{GAE} / \mathrm{g} \mathrm{DW}$ and from 2 to $11.60 \mathrm{mg} \mathrm{CE} / \mathrm{g} \mathrm{DW}$, respectively. Similarly, the flavonoid content of cultivated L. barbarum leaves (16.65 $\mathrm{mg} \mathrm{CE} / \mathrm{g} \mathrm{DW}$ ) was much higher than that of the wild $L$. barbarum leaves (7.55 CE/g DW) (Jing et al., 2009). These differences in results could be due to biotic (species, organ and physiological stage) and abiotic (environmental, handLing, and solvent extraction) factors, as previously shown by Ksouri et al. (2008). Also, the solubility of phenol compounds is governed by temperature. In this context, Yang et al. (2015) reported that the total polyphenol content of $L$. barbarum berries extracted with hot water

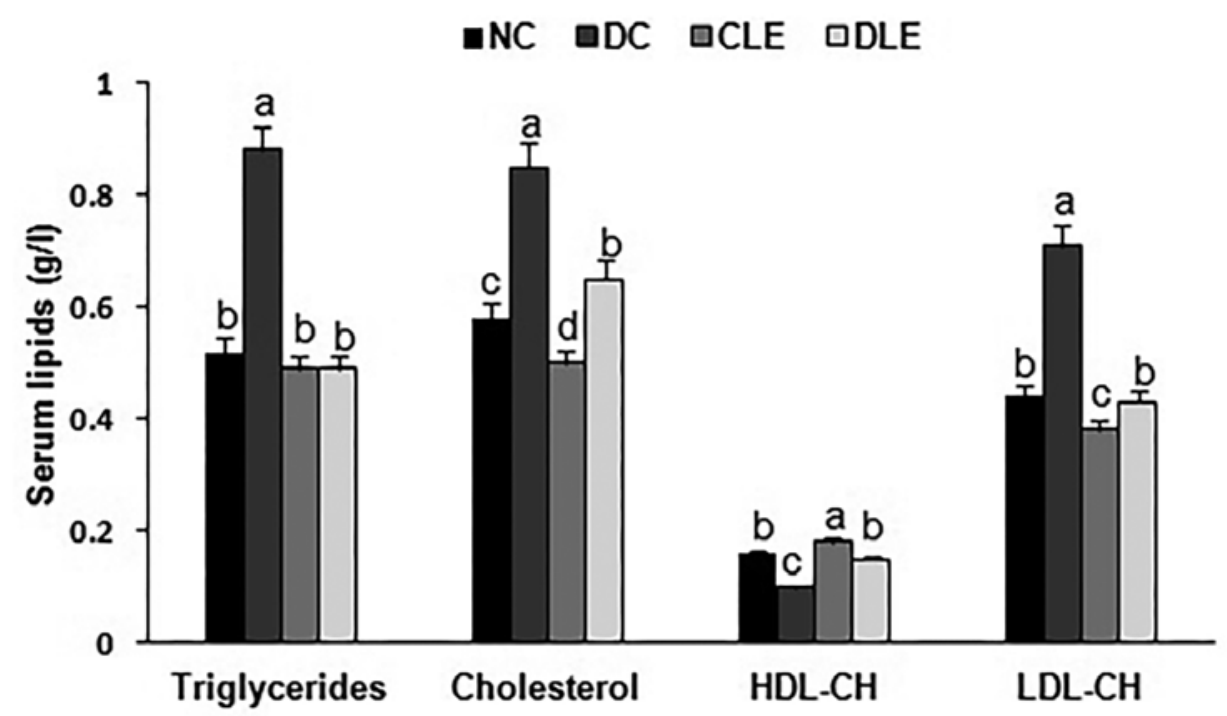

FIGURE 1 - Comparative levels of serum triglycerides, cholesterol, HDL-CH and LDL-CH in different rat groups. Groups are labelled as follows: Group NC: normal control, Group DC: diabetic control, Group CLE: Normal control fed with Lycium europaeum extract, Group DLE: Diabetic rats treated fed with Lycium europaeum extract. Data are expressed as mean \pm SD of measurements from 6 rats. Means not sharing common letters are significantly different among the groups at $P \leq 0.05$ as determined by Duncan's multiple range tests. 
Does Lycium europaeum leaf have antihyperglycemic, antihyperlipidemic and antioxidant effects

TABLE III - Effect of Lycium europaeum extract and/or alloxan treatment on SOD, CAT and GPx activities in plasma and pancreatic homogenates of treated rats

\begin{tabular}{|c|c|c|c|c|c|c|}
\hline & \multicolumn{6}{|c|}{ Antioxidant enzymes } \\
\hline & \multicolumn{3}{|c|}{ Pancreatic homogenate } & \multicolumn{3}{|c|}{ Plasma } \\
\hline & $\begin{array}{c}\text { SOD } \\
\text { (U/mg protein) }\end{array}$ & $\begin{array}{c}\text { CAT } \\
\text { (Mol H O /min/ } \\
\text { mg protein) }^{2}\end{array}$ & $\begin{array}{c}\text { GPx } \\
\left(10^{-3} \mathrm{mM} / \mathrm{min} /\right. \\
\mathrm{mg} \text { protein })\end{array}$ & $\begin{array}{l}\text { SOD } \\
(\mathrm{U} / \mathrm{mL})\end{array}$ & $\begin{array}{c}\text { CAT } \\
(\mathrm{U} / \mathrm{mL})\end{array}$ & $\begin{array}{c}\text { GPx } \\
(\mathbf{U} / \mathbf{m L})\end{array}$ \\
\hline $\mathrm{NC}$ & $26.4 \pm 3.5^{\mathrm{a}}$ & $56.9 \pm 4.2^{\mathrm{a}}$ & $2.9 \pm 0.6^{\mathrm{a}}$ & $459.5 \pm 26.3^{\mathrm{a}}$ & $9.9 \pm 1.2^{\mathrm{a}}$ & $637.5 \pm 37.2^{\mathrm{a}}$ \\
\hline DC & $10.8 \pm 1.4^{\mathrm{b}}$ & $20.4 \pm 1.8^{\mathrm{b}}$ & $0.8 \pm 0.2^{\mathrm{b}}$ & $228.4 \pm 15.7^{\mathrm{b}}$ & $3.9 \pm 0.9^{b}$ & $344.6 \pm 30.9^{b}$ \\
\hline CLE & $28.9 \pm 3.6^{\mathrm{a}}$ & $55.8 \pm 3.2^{\mathrm{a}}$ & $2.6 \pm 0.5^{\mathrm{a}}$ & $489.7 \pm 38.2^{\mathrm{c}}$ & $10.6 \pm 1.4^{\mathrm{a}}$ & $695.7 \pm 58.2^{c}$ \\
\hline DLE & $22.4 \pm 1.4^{\mathrm{a}}$ & $38.9 \pm 3.8^{\mathrm{c}}$ & $1.9 \pm 0.3^{\mathrm{c}}$ & $358.8 \pm 63.7^{\mathrm{d}}$ & $8.8 \pm 1.0^{\mathrm{a}}$ & $590.6 \pm 112.5^{\mathrm{d}}$ \\
\hline
\end{tabular}

Data are expressed as mean \pm SD of measurements from 6 rats. Groups are labeled as follows: Group NC: normal control, Group DC: diabetic control, Group CLE: normal control fed with Lycium europaeum extract, Group DLE: diabetic rats fed with Lycium europaeum extract. Different letters in the same raw indicate significant differences at $P \leq 0.05$ as determined by Duncan's multiple range tests.

was notably lower than that obtained otherwise (2.55 vs. $5.32 \%$ ). Meanwhile, Yujing et al. (2017) indicated that the contents of bioactive compounds and the antioxidant activity of $L$. barbarum infusions increased with time and temperature. Otherwise, Gupta et al. (2011) reported that flavonoids act as insulin secretagogues or insulin-mimetics by influencing the pleiotropic mechanisms to attenuate diabetic complications. The presence of flavonoids in L. europaeum may be responsible for the stimulation of glucose uptake in peripheral tissues and regulation of the activity and/or expression of the rate-limiting enzymes involved in the metabolism of carbohydrates.

The antioxidant capacity of plant extracts is assayed through several techniques. Each method relates to the generation or use of a different radical directly involved in the oxidative process, acting through a variety of mechanisms. Hence, no single assay can measure total antioxidant capacity (Milella et al., 2014). In this study, the antioxidant activities of $L$. europaeum extract were analyzed using three different and complementary assays: DPPH free radical scavenging, total antioxidant capacity and iron reducing power. The DPPH radical scavenging assay evaluated the ability of plant extracts to scavenge free radicals generated from DPPH reagent (Chung et al., 2006). In fact, DPPH is a stable free radical; when an antioxidant reacts with DPPH, the electron is paired off and the DPPH solution is decolorized. The scavenging activity of the antioxidant or the bleaching of the color stochiometrically depends on the number of electrons taken up (Shirwaikar, Patel, Kamariya, 2011). The present work also involved the evaluation of the antiradical activity of aqueous $L$. europaeum extract $\left(\mathrm{IC}_{50}=200 \mu \mathrm{g} / \mathrm{mL}\right)$ which was three fold higher than that obtained by Rjeibi et al. (2017) with $\mathrm{IC}_{50}=65.87 \mu \mathrm{g} / \mathrm{mL}$. It was observed that despite the inability of $L$. europaeum leaf extract to compete with the positive control BHT in scavenging DPPH $\left(\mathrm{IC}_{50}=24 \mu \mathrm{g} / \mathrm{mL}\right)$, this extract did possess mild antioxidant activity and may be considered as a potential preservative for medical applications. Additionally, our results showed $L$. europaeum leaves to have a strong antioxidant capacity (17 mg GAE/g DW). This finding was consistent with Tawaha et al. (2007) who proved that the total antioxidant activity was remotely correlated to the content of flavonoids and polyphenols. The antioxidant activity of polyphenols is also due to their red-ox properties that make them act as reducing agents, hydrogen donors and singlet oxygen quenchers. The third antioxidant capacity was measured in terms of the iron reducing power. A low $\mathrm{EC}_{50}(92 \mu \mathrm{g} / \mathrm{mL})$ was obtained, which indicated a higher reducing power activity. Antioxidants reducing the ferric ion/ferricyanide complex to the ferrous form of the extracts may provide a significant indication of the potential antioxidant capacity of the plant. The reducing properties are generally connected to the presence of reductones, which exert antioxidant activity by breaking the free radical chain through the donation of a hydrogen atom (Xing et al., 2005). Therefore, the potent antioxidant activity of $L$. europaeum leaves might be related to the presence of secondary metabolites such as polyphenols and flavonoids. In this way, Rjeibi et al. (2017) reported that the chemical composition of L. europaeum leaf extract was rich in phenolic acids, namely caffeic $(140.18 \mu \mathrm{g} / \mathrm{g})$, gallic $(117.17 \mu \mathrm{g} / \mathrm{g})$, vanillic $(26.54 \mu \mathrm{g} / \mathrm{g})$ and coumaric $(1.38 \mu \mathrm{g} / \mathrm{g})$ acids, and flavonoids, namely naringenin $(57.18 \mu \mathrm{g} / \mathrm{g})$, epicatechin $(33.14 \mu \mathrm{g} / \mathrm{g})$, rutin $(25.16 \mu \mathrm{g} / \mathrm{g})$, kaempferol $(12.33 \mu \mathrm{g} / \mathrm{g})$, 
catechin $(10.66 \mu \mathrm{g} / \mathrm{g})$, luteolin $(9.85 \mu \mathrm{g} / \mathrm{g})$, apigenin $(9.47 \mu \mathrm{g} / \mathrm{g})$ and quercetin $(1.53 \mu \mathrm{g} / \mathrm{g})$.

In order to evaluate the capacity of $L$. europaeum leaf extract to cure diabetes, alloxan was used to induce hyperglycemia in rats. Alloxan has been recognized as a convenient experimental model to evaluate the activity of hypoglycemic agents (Ramkumar et al., 2009). It destroys the $\beta$-cells of islets in the pancreas Langerhans, resulting in a depletion of endogenous insulin secretion and leading to a decreased utilization of glucose by body tissues (Szkudelski, 2001). Obtained results showed that the administration of $L$. europaeum extract induces an increase in animal body weight in both control and diabetic rats. Additionally, L. europaeum leaf extract proved a potent hypoglycemic effect starting at one week of treatment in diabetic rats (DLE vs. DC groups) and continued for four weeks, reaching $49.3 \%$ at the end of the experimental period. Several studies in the last decades have shown that plant and plant-based therapies have a potential to control and treat diabetes and its complications (Marles, Farnsworth, 1995). The ability of this plant extract to reduce blood glucose level could be attributed to an improvement of the peripheral sensitivity to remnant insulin or to its capacity to induce stimulation of Langerhans islets. In fact, alloxan is known to induce free radical production and cause tissue injury. The pancreas is specifically susceptible to the action of alloxan-induced free radical damage. As reported by Akah, Uzodinma and Okolo (2011), the regeneration of islet $\beta$-cells after destruction by alloxan may be the primary recovery mechanism of alloxan-injected rats following plant extract administration. In addition, L. europaeum leaf extract was characterized by the presence of wellknown antioxidant phytochemicals, namely phenolic acids (caffeic, gallic, vanillic and coumaric acids) and flavonoids (naringenin, epicatechin, rutin, kaempferol, catechin, luteolin, apigenin and quercetin) as mentioned by Rjeibi et al. (2017). Several studies have mentioned the antidiabetic effect of caffeic acid (Jung et al., 2006), gallic acid (Adeniyi et al., 2015), coumaric acid (Amalan et al., 2016), naringenin (Ortiz-Andrade et al., 2008), catechin (Liu et al., 2014), rutin (Ghorbani, 2017), kaempferol (Al-Numair et al., 2015), luteolin (Zang, Igarashi, Li, 2016), apigenin (Cazarolli et al., 2012) and quercetin (Vessal, Hemmati, Vasei, 2003). These compounds influence glucose metabolism by several mechanisms, such as inhibition of carbohydrate digestion and glucose absorption in the intestine, stimulation of insulin secretion from the pancreatic $\beta$-cells, modulation of glucose release from the liver, activation of insulin receptors and glucose uptake in insulin-sensitive tissues and the modulation of hepatic glucose production (Hanhineva et al., 2010). Therefore, L. europaeum leaf extract could be prescribed as therapy for DM.

The chronic hyperglycemia of diabetes is associated with the long-term damage, dysfunction and failure of various organs, especially eyes, kidneys, nerves, heart and blood vessels (Baynes, 1991). DM is also related to a hyperlipidemia and leads to serious anomalies in lipid composition and concentration (Cooperstin, Watkin, 1981). Abnormal lipid metabolism leads to the accumulation of plasma TG, LDL and TC, as well as decreased HDL-C, commonly associated with diabetes (Kondeti et al., 2010). As reported by Betterridge (2002), the insulin deficiency or insulin resistance may be responsible for hyperlipidemia due to the insulin inhibiting action on the 3-hydroxy-3methyl-methylglutaryl coenzyme-A which is a key enzyme in cholesterol biosynthesis. Due to diabetes, the hyperlipidemia may be regarded as a result of the non-inhibiting action of lipolytic hormones on adipose tissues (Goodman, Gilman, 1985). Our results showed that serum TG, TC and LDL-C levels were significantly increased $(p<0.05)$ in diabetic groups (DC, DLE) in comparison to controls (NC, CLE) whereas HDL-C was significantly decreased $(p<0.05)$ in the diabetic groups in comparison to control groups. On the other hand, L. europaeum was also able to improve some lipid metabolites. In fact, treatment with this plant for four weeks resulted in reduced TG, TC and LDL-C levels compared to untreated diabetic rats while serum HDL-C levels were significantly $(p<0.05)$ increased in treated diabetic rats. This data demonstrates for the first time that, in addition to its hypoglycemic effect, $L$. europaeum leaf extract can significantly improve the imbalance in lipid metabolism. Moreover, the reduced TC and increased HDL-C levels following L. europaeum administration were noteworthy, according to Wang et al. (2010), who reported that most drugs used in the treatment of hypercholesterolaemia reduced both total and HDL-C levels. Additionally, the polyphenols and flavonoids of L. europaeum extract, which contribute to its antioxidant properties, may play a synergistic role in its hypolipidemic effect. As reviewed by Bahadoran, Mirmiran and Azizi (2013), polyphenols have powerful modulator effects on many aspects of metabolic, endocrine and cellular signaling transduction of adipose tissue. They also reported that some polyphenols such as catechins increase $\beta$ oxidation in adipocytes and down-regulate the enzymes and genes involved in lipogenesis, including lipoprotein lipase, fatty acid synthase complex, peroxisome proliferators-activated 
receptor $\gamma$, regulatory element-binding protein $1-\mathrm{c}$ and fatty acid binding protein. To the best of our knowledge, this is the first report on the hypolipidemic effect of $L$. europaeum leaf extract. Thus, it is reasonable to conclude that L. europaeum leaf extract could modulate blood lipid abnormalities by acting as a potential hypolipidemic agent.

Oxidative stress, due to increased free radical formation and reduced antioxidant status, is widely believed to be a key factor in the pathogenesis and progression of diabetes (Punithavathi et al., 2011). Available evidence strongly suggests that excessive free radicals, particularly reactive oxygen species (ROS) generated from hyperglycemia-induced glucose autooxidation and protein glycosylation, play a critical role in diabetes (Masjedi, Gol, Dabiri, 2013). Reddy et al. (2005) showed a close relationship between the increase of free radicals, blood glucose and lipid peroxidation in the induction of diabetes. Increased lipid peroxidation damages membrane function by decreasing membrane fluidity and changing the activity of membrane-bound enzymes and receptors (Verma, Itankar, Arora, 2013). Enzymatic antioxidants, such as SOD, CAT and GPx, play a vital role in preventing oxidative damage to the cells. Because of the unbalanced oxidant/antioxidant system in DM and its involvement in the mechanism of various pathological complications, the effect of the aqueous leaf extract of L. europaeum on oxidative stress was investigated. Our results corroborated previous works that have demonstrated that an increased blood glucose level induces a depletion of the antioxidant system (Punitha, Manoharan, 2006; Vina et al., 2006; Shabeer, Srivastava, Singh, 2009). The enzyme activity reductions observed in the diabetic control group suggest their excessive utilization in attenuating free radicals generated during the metabolism of alloxan, as it was already reported in diabetic animals (Onyeka, Nwakanma, Bakare, 2013). L. europaeum extract prevented this decrease, especially for SOD activity in pancreatic homogenate and CAT activity in serum, which became comparable to normal control values. SOD scavenges the superoxide radicals by converting them to $\mathrm{H}_{2} \mathrm{O}_{2}$ and molecular oxygen. The observed decrease in SOD activity in diabetic control rats could result from inactivation by $\mathrm{H}_{2} \mathrm{O}_{2}$ or by glycosylation of the enzyme, which have been reported to occur in diabetes. Meanwhile, the increase in its activities is an indication of its ability to scavenge ROS, thus contributing to the protective effect against oxidative stress and preventing further damage to membrane lipids. Natural antioxidant agents fundamentally originate from plants in the form of secondary metabolites (Marjorie, 1996). The presence of different types of bioactive components, like phenolic acids and flavonoids in L. europaeum extract, could be responsible for the antidiabetic activities (Sharma, 2012) since they could scavenge free radicals, quench electronically excited compounds, reduce hydroperoxide formation, and attenuate production of ROS through the modulation of several pro-oxidant enzymes involved in the development of ROS, including xanthine oxidase, cyclooxygenase, lipoxygenase, microsomal monooxygenase, NADH oxidase and mitochondrial succinoxidase (Dembinska-Kiec et al., 2008). In fact, these bioactive components decreased lipid peroxidation and increased plasma total antioxidant capacity; they also attenuated stress-sensitive signaling pathways, pro-oxidant enzymes, and inducted antioxidant enzymes including SOD, CAT and GPx (Crespy, Williamson, 2004). Thus, the antidiabetic effect of $L$. europaeum extracts might be due to these bioactive constituents.

\section{CONCLUSION}

Currently, medical prevention and treatment of diabetic complications are mainly based on the optimized control of blood glucose. According to our findings, $L$. europaeum leaf extract has beneficial effects on blood glucose in diabetic rats, thus revealing its antidiabetic potential. L. europaeum extract was also able to restore altered levels of serum lipids and endogenous antioxidant enzymes revealing its antihyperlipidemic and antioxidant potential. These putative effects may be due to the additive effects of bioactive constituents present in the aqueous extract. Moreover, the consumption of L. europaeum leaf extract could be considered a good complementary source of natural antioxidant and as an adjunct therapy in the management of diabetes. However, intensive investigations must be conducted on the extract fractions to identify pharmacological active compound(s), to establish the possible mechanism(s) of action and to set appropriate doses.

\section{CONFLICTS OF INTEREST}

All contributing authors declare no conflicts of interest.

\section{ACKNOWLEDGEMENT}

The authors are grateful to Kamel MAALOUL, Translator and English professor for having proofread the manuscript. 


\section{REFERENCES}

Adeniyi Adefegha S, ObohIsaac G, Ejakpovi I, Idowu Oyeleye S. Antioxidant and antidiabetic effects of gallic and protocatechuic acids: a structure-function perspective. Comp Clin Path. 2015;24(6):1579-1585.

Aebi H. Catalase in vitro. Methods Enzymol. 1984;105(1):121126.

Akah PA, Uzodinma SU, Okolo CE. Antidiabetic activity of aqueous and methanol extract and fractions of Gongronema latifolium (asclepidaceae) leaves in alloxan diabetic rats. J App Pharm Sci. 2011;1(9):99-102.

Al-Numair KS, Chandramohan G, Veeramani C, Alsaif MA. Ameliorative effect of kaempferol, a flavonoid, on oxidative stress in streptozotocin-induced diabetic rats. Redox Rep. 2015;20(5):198-209.

Amagase H, Farnsworth NR. A review of botanical characteristics, photochemistry, clinical relevance in efficacy and safety of Lycium barbarum fruit (Goji). Food Res Int. 2011;44(1):1702-1717.

Amalan V, Vijayakumar N, Indumathi D, Ramakrishnan A. Antidiabetic and antihyperlipidemic activity of $p$-coumaric acid in diabetic rats, role of pancreatic GLUT 2: In vivo approach. Biomed Pharmacother. 2016;84(1):230-236.

Ayiguli A, Wang Y, Yang XJ, Han HX, Bao XW, Zhu JF, Yu NN. Study on extraction method and assay of polysaccharides of Lycium barbarum L. from two different sources. XAAS. 2007;10(4)724-728.

Bahadoran Z, Mirmiran P, Azizi F. Dietary polyphenols as potential nutraceuticals in management of diabetes: a review. $\mathrm{J}$ Diabetes Metab Desord. 2013;12(1):43-52.

Baynes JW. Role of oxidative stress in development of complications in diabetes. J Diabetes. 1991;40(4):405-12.

Betterridge J. Lipid disorders in diabetes mellitus. In: Pickup J, Williams G (editors). Textbook of Diabetes. Malden, Mass: Blackwell Science; 2002; 551-553.

Beyer WF, Fridovich I. Assaying for superoxide dismutase activity: Some large consequences of minor changes in conditions. Anal Biochem. 1987;161(2):559-566.
Capewell S, Ford ES, Croft JB, Critchley KJ, Labarthe DR. Cardiovascular risk factor trends and potential for reducing coronary heart disease mortality in the United States of America. Bull World Health Organ. 2010;88(2):120-130.

Cazarolli LH, Kappel VD, Pereira VF, Moresco HH, Brighente IMC, Pizzolatti MG, Silva FR. Anti-hyperglycemic action of apigenin-6-C- $\beta$-fucopyranoside from Averrhoa carambola. Fitoterapia. 2012;83(7):1176-1183

Chung YC, Chien CT, Teng KY, Chou ST. Antioxidative and mutagenic properties of Zanthoxylum ailanthoides Sieb \& zucc. Food Chem. 2006;97(3):418-425.

Cooperstin SJ, Watkin D. Action of toxic drugs on islet cells. In the islets of langerhans, New York: Academic Press; 1981; 387-425.

Crespy V, Williamson G. A review of the health effects of green tea catechins in vivo animal models. J Nutr. 2004;134(12):3431S-3440S.

Dahech I, Farah W, Trigui M, Hssouna AB, Belghith H, Belghith KS, Abdallah FB. Antioxidant and antimicrobial activities of Lycium shawii fruits extract. Int J Biol Macromol. 2013;60(1):328-333.

Dembinska-Kiec A, Mykkänen O, Kiec-Wilk B, Mykkänen H. Antioxidant phytochemicals against type 2 diabetes. Br J Nutr. 2008;99(1):ES109-ES117.

Deshpande AD, Harris-Hayes M, Schootman M. Epidemiology of diabetes and diabetes-related complications. Phys Ther. 2008;88(11):1254-1264.

Dewanto V, Wu X, Adom KK, Liu RH. Thermal processing enhances the nutritional value of tomatoes by increasing total antioxidant activity. J Agric Food Chem. 2002;50(10):30103014.

Dey L, Attele AS, Yuan CS. Alternative therapies for type 2 diabetes. Altern Med Rev. 2002;7(1):45-58.

El Faramawy SM, Rizk RA. Spectrophotometric studies on antioxidants-doped liposomes. J Am Sci. 2011;7(7):363-369.

El-Abhar HS, Schaalan MF. Phytotherapy in diabetes: Review on potential mechanistic perspectives. World J Diabetes 2014;5(2):176-197. 
Flohe L, Gunzler WA. Assays of glutathione peroxidase. Methods Enzymol. 1984;105(1):114-121.

Ghorbani A, Omrani GH, Hadjzadeh MR, Varedi M. Proinsulin C-peptide inhibits lipolysis in diabetic rat adipose tissue through phosphodiestrase-3B enzyme. Horm Metab Res. 2013;45(3):221-225.

Ghorbani A. Mechanisms of antidiabetic effects of flavonoid rutin. Biomed Pharmacother. 2017;96(1):305-312.

Goldstein JL, Schrott HG, Hazzard WR, Bieman EL, Motulsky AG. Hyperlipidemia in coronary heart disease. II. Genetic analysis of lipid levels in 176 families and delineation of a new inherited disorder, combined hyperlipidemia. J Clin Invest. 1973;52(7):1544-1568.

Goodman LS, Gilman A. The Pharmacological Basis of Therapeutics. New York: Macmillan; 1985; 1490-1510.

Gupta R, Mathur M, Bajaj VK, Katariya P, Yadav S, Kamal R, Gupta RS. Evaluation of antidiabetic and antioxidant activity of Moringa oleifera in experimental diabetes. J Diabetes. 2012;4(2):164-171.

Gupta R, Sharma AK, Dobhal MP, Sharma MC, Gupta RS. Antidiabetic and antioxidant potential of $\beta$-sitosterol in streptozotocin-induced experimental hyperglycemia. J Diabetes. 2011;3(1):29-37.

Hanhineva K, Törrönen R, Bondia-Pons I, Pekkinen J, Kolehmainen M, Mykkänen H, Poutanen K. Impact of dietary polyphenols on carbohydrate metabolism. Int J Mol Sci. 2010;11(4):1365-1402.

Haskins K, BradLey BK. Powers Oxidative stress in type 1 diabetes. Ann NY Acad Sci. 2003;1005(1):43-54.

Hatano T, Kagawa H, Yasuhara T, Okuda T. Two new Flavonoids and other constituents in licorice root: their relative astringency and radical scavenging effects. Chem Pharm Bull. 1988;36(6):2090-2097.

Jin ML, Huang QS, Zhao K, Shang P. Biological activities and potential health benefit effects of polysaccharides isolated from Lycium barbarum L. Int J Biol Macromol. 2013;54(1):16-23.

Jing Z, Dong J, Lu DY, Wang Y. Analysis of flavonoids from leaves of cultivated Lycium barbarum L. Plant Foods Hum. Nutr 2009;64(3):199-204.
Jung UJ, Lee MK, Park YB, Jeon SM, Choi MS. Antihyperglycemic and antioxidant properties of caffeic acid in $\mathrm{db} / \mathrm{db}$ mice. J Pharmacol Exp Ther. 2006;318(2):476-483.

Kondeti VK, Badri KR, Maddirala DR, Thur SK, Fatima SS, Kasetti RB, Rao CA. Effect of Pterocarpus santalinus bark, on blood glucose, serum lipids, plasma insulin and hepatic carbohydrate metabolic enzymes in streptozotocin-induced diabetic rats, Food Chem Toxicol. 2010;48(5):1281-1287.

Ksouri R, Megdiche W, Falleh H, Trabelsi N, Boulaaba M, Smaoui A, Abdelly C. Influence of biological, environmental and technical factors on phenolic content and antioxidant activities of Tunisian halophytes. C R Biol. 2008;331(11):865873.

Kwon MJ, Song YS, Choi MS. Cholesteryl ester transfer protein activity and atherogenic parameters in rabbits supplemented with cholesterol and garlic powder. Life Sci. 2003;72(26):29532964.

Liu J, Lu JF, Kan J, Wen XY, Jin CH. Synthesis, characterization and in vitro anti-diabetic activity of catechin grafted inulin. Int J Biol Macromol. 2014;64(1):76-83.

Lowry OH, Rosenbrough NJ, Farr AL, Randall RJ. Protein measurement with the folin phenol reagent. J Biol Chem. 1951;1(1):265-275.

Luo Q, Cai YZ, Yan J, Sun M, Corke H. Hypoglycemic and hypolipidemic effects and antioxidant activity of fruit extracts from Lycium barbarum. Life Sci. 2004;76(2):137-149.

Marjorie C. Plant products as antimicrobial agents, Clin Microbiol Rev. 1996;12(4):564-582.

Marles RJ, Farnsworth NR. Antidiabetic plants and their active constituents. Phytomed. 1995;2(2):137-189.

Masjedi F, Gol A, Dabiri S. Preventive effect of garlic (Allium sativum L.) on serum biochemical factors and histopathology of pancreas and liver in streptozotocin-induced diabetic rats. Iran J Pharmacol Res. 2013;12(3):325-338.

Milella L, Bader A, De Tommasi N, Russo D, Braca A. Antioxidant and free radical-scavenging activity of constituents from two Scorzonera species. Food Chem. 2014;160(1):298304. 
Onyeka CA, Nwakanma AA, Bakare AA. Hypoglycemic, antioxidant and hepatoprotective activities of ethanolic root bark extract of Chrysophyllum albidum in alloxan-induced diabetic rats. Bangla J Med Sci. 2013;12(3):298-304.

Ortiz-Andrade RR, Sánchez-Salgado JC, Navarrete-Vázquez G, Webster SP, Binnie M, García-Jiménez S, León-Rivera I, Cigarroa-Vázquez P, Villalobos-Molina R, Estrada-Soto S. Antidiabetic and toxicological evaluations of naringenin in normoglycaemic and NIDDM rat models and its implications on extra-pancreatic glucose regulation. Diabetes Obes Metab. 2008;10(11):1097-1104.

Oyaizu M. Studies on products of the browning reaction prepared from glucose amine. Jap J Nutr. 1986;44(6):307-315.

Prieto P, Pineda M, Aguilar A. Spectrophotometric quantitation of antioxidant capacity through the formation of a phosphomolybdenum complex: Specific application to the determination of vitamin E. Anal Biochem. 1999;269(2):337341.

Punitha R, Manoharan S. Antihyperglycemic and antilipidperoxidative effects of Pongamia pinnata (Linn). Pierre flowers in alloxan induced diabetic rats. J Ethnopharmacol. 2006;105(1-2):39-46.

Punithavathi VR, Prince PSM, Kumar R, Selvakumari J. Antihyperglycaemic. antilipidperoxidative and antioxidant effects of gallic acid on streptozotocin induced diabetic wistar rats. Eur J Pharmacol. 2011;650(1):465-471.

Ramachandran S, Rajasekaran A, Manisenthilkumar KT. Investigation of hypoglycemic, hypolipidemic and antioxidant activities of aqueous extract of Terminalia paniculata bark in diabetic rats. Asian Pac J Trop Biomed. 2012;2(4):262-8.

Ramkumar KM, Ponmanickam P, Velayuthapra Bhu S, Archunang G, Raja Guru P. Protective effect of gymnem amontanum against renal damage in experimental diabetic rats. Food Chem Toxicol. 2009;47(10):2516-2521.

Reddy SV, Tiwari AK, Kumar US, Rao RJ, Rao JM. Free radical scavenging, enzyme inhibitory constituents from antidiabetic Ayurvedic medicinal medicinal plant Hydnocarpus wightiana Blum. Phytother Res. 2005;19(4):277-281.

Rees DA, Alcolado JC. Animals models of diabetes. Diab Med. 2005;22(4):359-370.
Rjeibi I, Feriani A, Ben Saada A, Ncib S, Sdayria J, Saidia I, Souid S, Hfaiedh N, Allagui MS. Phytochemical characterization and bioactivity of Lycium europaeum: A focus on antioxidant, antinociceptive, hepatoprotective and nephroprotective effects. Biomed Pharmacother. 2017;95(1):1441-1450.

Said O, Khalil K, Fulder S, Azaizeh H. Ethnopharmacological survey of medicinal herbs in Israel, the Golan Heights and the West Bank region. J Ethnopharmacol. 2002;83(3):251-265.

Sefi M, Fetoui H, Makni M, Zeghal N. Mitigating effects of antioxidant properties of Artemisia campestris leaf extract on hyperlipidemia. advanced glycation and products and oxidative stress in alloxan-induced diabetic rats. Food Chem. Toxicol. 2010;48(7):1986-1993.

Shabeer J, Srivastava RS, Singh SK. Antidiabetic and antioxidant effect of various fractions of Phyllanthus simplex in alloxan diabetic rats. J Ethnopharmacol. 2009;124(1):34-38.

Sharma RR. Preliminary phytochemical screening of some indigenous medicinal plant leaves extract in regulation of antidiabetic activity. Sci Res Rep. 2012;2(3):307-310.

Shirwaikar A, Patel B, Kamariya Y. In vitro free radical scavenging potential of defatted ethanolic extract of the seeds of Lepidium sativum Linn. Chin J Nat Med. 2011;9(6):435-440.

Szkudelski T. The mechanism of alloxan and streptozotocin action in B cells of the rat pancreas. Physiol Res. 2001;50(6):537546.

Tawaha K, Alali FQ, Gharaibeh M, Mohammad M, El-Elimat T. Antioxidant activity and total phenolic content of selected Jordanian plant species. Food Chem. 2007;104 (4) 1372-1378.

Tiwari AK, Rao JM. Diabetes mellitus and multiple therapeutic approaches of phytochemicals: Present status and future prospects. Curr Sci. 2002;83(1):30-38.

Verma PR, Itankar PR, Arora SK. Evaluation of antidiabetic antihyperlipidemic and pancreatic regeneration, potential of aerial parts of Clitoria ternatea. Rev Bras Farmacogn. 2013;23(5):819-829

Vessal M, Hemmati M, Vasei M. Antidiabetic effects of quercetin in streptozocin-induced diabetic rats. Comp Biochem Physiol Toxicol Pharmacol. 2003;135(3):357-364. 
Vina J, Borras C, Gomez-Cabrera MC, ORR WC. Role of reactive oxygen species and (phyto) oestrogens in the modulation of adaptive response to stress. Free Radic Res. 2006;40(2):111-119.

Wang L, Zhang XT, Zhang HY, Yao HY, Zhang H. Effect of Vaccinium bracteatum Thunb. leaves extract on blood glucose and plasma lipid levels in streptozotocin-induced diabetic mice. J Ethnopharmacol. 2010;130(3):465-469.

WHO. World Health Organization, Global status report on noncommunicable diseases 2010. Geneva. 2011.

WHO. World Health Organization. Definition and diagnosis of diabetes mellitus and intermediate hyperglycaemia: Report of a WHO/IDF consultation. Geneva: World Health Organization. 2006.

Winkler G, Hidvegit T, Wandorfi G, Jermendy G. Risk-stratified screening for diabetes in adult subjects: results of the first investigation in Hungary. Orv Hetil. 2010;151(17):691-696.

Xing R, Liu S, Guo Z, Yu H, Wang P, Li C, Li Z, Li P. Relevance of molecular weight of chitosan and its derivatives and their antioxidant activities in vitro. Bioorg Med Chem. 2005;13(5):1573-1577.
Yang R, Zhao C, Chen X, Chan S, Wu J. Chemical properties and bioactivities of Goji (Lycium barbarum) polysaccharides extracted by different methods. J Funct Foods. 2015;17(1):903909.

Yujing S, Japaer R, Wenyang T, Peilong S, Xingqian Y. Bioactive compounds and antioxidant activity of wolfberry infusion. Sci Rep. 2017;7(1):40605.

Zang Y, Igarashi K, Li Y. Anti-diabetic effects of luteolin and luteolin-7-O-glucoside on KK-A(y) mice. Biosci Biotechnol Biochem. 2016;80(8):1580-1586.

Zhao R, Li QW, Li J, Zhang T. Protective effect of Lycium barbarum polysaccharide 4 on kidneys in streptozotocininduced diabetic rats. Can J Physiol Pharmacol. 2009;87(9):711719.

Zhu J, Liu W, Yu JP, Zou S, Wang JJ, Yao WB, Gao XD. Characterization and hypoglycemic effect of a polysaccharide extracted from the fruit of Lycium barbarum L. Carbohydr Polym. 2013;98(1):8-16.

Received for publication on $14^{\text {th }}$ March 2018 Accepted for publication on $16^{\text {th }}$ April 2018 